\title{
Feasibility of bioethanol production from rice bran
}

\section{Viabilidade da produção de bioetanol a partir do farelo de arroz}

\author{
Francieli Begnini Siepmann'; Daneysa Lahis Kalschne ${ }^{2 *}$; Caroline Zabotti; \\ Eder Lisandro de Moraes Flores ${ }^{4}$; Cristiane Canan ${ }^{5}$; Eliane Colla ${ }^{5}$
}

\section{Highlights:}

Rice bran protein hydrolysis allowed an increase in the final bioethanol production.

Temperature and inoculum concentration affect the bioethanol production.

Optimized temperature and an inoculum allowed to produce $40.70 \mathrm{~g} \mathrm{~L}^{-1}$ of bioethanol.

Validation in benchtop bioreactor produced $40.0 \mathrm{~g} \mathrm{~L}^{-1}$ of bioethanol from rice bran.

Sequential design and protease addition improve bioethanol production from rice bran.

\begin{abstract}
Rice bran is a by-product of rice production with a high carbohydrate and starch content and the potential for bioethanol production by alcoholic fermentation. This article describes bioethanol production by Saccharomyces cerevisiae from hydrolyzed defatted rice bran (DRB) a rice by-product applying ultrasonic treatment and protease addition, as well as a sequential strategy of experimental design (SEED). In the first Central Composite Rotatable Design (CCRD), the temperature (25-30 ${ }^{\circ} \mathrm{C}$ ) and inoculum concentration $\left(0.5-50 \mathrm{~g} \mathrm{~L}^{-1}\right)$ had positive effects on bioethanol production, while the effect of $\mathrm{pH}$ (4.0-6.0) was not significant. In the second CCRD, the temperature $\left(28-35^{\circ} \mathrm{C}\right)$ and inoculum concentration (10-70 $\left.\mathrm{g} \mathrm{L}^{-1}\right)$ had negative and positive effects on bioethanol production ( $\mathrm{p}$ $<0.05)$. Protease addition $\left(15 \mu \mathrm{L} \mathrm{g}^{-1}\right)$ increased the conversion of substrate into bioethanol by $76 \%$. The optimized conditions for the production of $40.7 \mathrm{~g} \mathrm{~L}^{-1}$ bioethanol were a temperature of $31.5^{\circ} \mathrm{C}$ and an inoculum concentration of $70 \mathrm{~g} \mathrm{~L}^{-1}$. Validation in a benchtop bioreactor produced $40.0 \mathrm{~g} \mathrm{~L}^{-1}$ of bioethanol from hydrolyzed DRB, and the SEED was characterized as a useful tool to improve bioethanol production from DRB. Furthermore, the DRB proved to be a by-product with great potential for bioethanol production, derived from alternative sources not commonly used in human food.

Key words: Enzymatic hydrolysis. Ultrasonic treatment. Protease. Response surface methodology.
\end{abstract} Alcoholic fermentation.

\section{Resumo}

O farelo de arroz é um subproduto com alto teor de carboidratos e amido, com potencial para produção de bioetanol por fermentação alcoólica. O presente artigo descreve a produção de bioetanol pela ação da Saccharomyces cerevisiae no farelo de arroz desengordurado hidrolisado (DRB) - um subproduto

\footnotetext{
${ }^{1}$ Discente do Curso de Mestrado do Programa de Pós-Graduação em Tecnologia de Alimentos, Departamento de Alimentos, Universidade Tecnológica Federal do Paraná, UTFPR, Medianeira, PR, Brasil. E-mail: franbegnini@gmail.com

2 Pós-Doutoranda do Curso de Mestrado do Programa de Pós-Graduação em Tecnologia de Alimentos, Departamento de Alimentos, UTFPR, Medianeira, PR, Brasil. E-mail: daneysa@hotmail.com

3 Discente do Curso de Graduação em Engenharia de Alimentos, Departamento de Alimentos, UTFPR, Medianeira, PR, Brasil. E-mail: carolzabotti@hotmail.com

4 Prof., Curso de Mestrado do Programa de Pós-Graduação em Tecnologias Ambientais, Departamento de Química, UTFPR, Medianeira, PR, Brasil. E-mail: eder@utfpr.edu.br

5 Prof ${ }^{\text {as }}$, Curso de Mestrado do Programa de Pós-Graduação em Tecnologia de Alimentos, Departamento de Alimentos, UTFPR, Medianeira, PR, Brasil. E-mail: canan@utfpr.edu.br; ecolla@utfpr.edu.br

* Autthor for correspondence
} 
do arroz - com a aplicação do tratamento ultrassônico e adição de protease, e estratégia sequencial de planejamento experimental (SEED). No primeiro Delineamento Composto Central Rotacional (CCRD), a temperatura $\left(25-30^{\circ} \mathrm{C}\right)$ e a concentração de inóculo $\left(0,5-50 \mathrm{~g} \mathrm{~L}^{-1}\right)$ tiveram efeitos positivos na produção de bioetanol, enquanto o $\mathrm{pH}(4,0-6,0)$ não foi significativo. No segundo CCRD, a temperatura (28-35 $\left.{ }^{\circ} \mathrm{C}\right)$ e a concentração do inóculo (10-70 $\left.\mathrm{g} \mathrm{L}^{-1}\right)$ tiveram efeitos negativo e positivo, respectivamente, na produção de bioetanol $(\mathrm{p}<0,05)$. A adição de protease $\left(15 \mu \mathrm{L} \mathrm{g}^{-1}\right)$ aumentou a conversão do substrato em bioetanol em $76 \%$. Na temperatura de $31,5^{\circ} \mathrm{C}$ e concentração de inóculo de $70 \mathrm{~g} \mathrm{~L}^{-1}$ obteve-se a condição otimizada para produção de bioetanol, com a produção de $40,7 \mathrm{~g} \mathrm{~L}^{-1}$. Na validação, realizada em um fermentador de bancada, foram produzidos $40,0 \mathrm{~g} \mathrm{~L}^{-1}$ de bioetanol a partir de DRB hidrolisado; e o SEED foi caracterizado como uma ferramenta útil para otimizar a produção de bioetanol a partir de DRB. Além disso, o DRB provou ser um subproduto com grande potencial para a produção de bioetanol, derivado de fontes alternativas normalmente não utilizadas na alimentação humana.

Palavras-chave: Hidrólise enzimática. Tratamento ultrassônico. Protease. Superfície de resposta. Fermentação alcoólica.

\section{Introduction}

Bioethanol, a sustainable and renewable fuel used for transportation, aids $21^{\text {st }}$ century society in its endeavor to meet the growing energy demand for transportation and industrial processes. A large portion of the bioethanol currently produced in the world is derived from sugar or starch crops and therefore competes directly with food sources. Bioethanol production requires the development of a sustainable process using renewable by-products composed of lignocellulose and starch to remain economically viable (Das et al., 2013; Hayes, 2009).

Brazil is the largest producer of rice (Oryza sativa) outside Asia. The estimate for these countries' rice crop in 2019/2020 reached 10,563 thousand tons in a cultivated area of 1,685 ha (CONAB, 2020). One of the by-products generated during the production of polished rice is rice bran. This by-product represents between $8 \%$ and $11 \%$ of the total rice grain weight (Parrado et al., 2006) and presents a high content of protein $(15 \%)$, fat (21\%), total carbohydrates (52\%) and starch (15\%) (Amagliani, O’Regan, Kelly, \& O'Mahony, 2017). The concentrations of carbohydrates justify the use of rice bran in fermentative processes as for bioethanol production. However, the presence of nutrients such as protein and lipids may reduce the yeast's performance (Watanabe, Honda, Kashiwamura, Sasano, \& Watanabe, 2009a). Defatted rice bran
(DRB) has lower concentrations of fat $(<2 \%)$ and higher protein $(18 \%)$, total carbohydrates $(60 \%)$, and starch (21\%) contents (Watanabe et al., 2019). Thus, the hydrolysis of DRB proteins is an option to increase the bioethanol yield considering that several studies (Johnston \& McAloon, 2014; Lei, Zheng, Wang, Zhao, \& Zhao, 2013; Watanabe et al., 2009b; Yao, Lee, Wang, Moura, \& Johnson, 2012) demonstrated that the addition of a protease resulted in an increase in the final bioethanol concentration.

The amino acids released during protein hydrolysis increase the concentration of nitrogen, an essential macronutrient for the action of yeast, in the medium. Some studies (Mendes-Ferreira, MendesFaia, \& Leão, 2004) evaluated the growth of $S$. cerevisiae and fermentation of wines using different initial concentrations of nitrogen (16.5 to $805 \mathrm{mg}$ $\left.\mathrm{L}^{-1}\right)$ supplemented by the addition of diammonium sulfate or a mixture of amino acids and observed an increase in yeast growth (biomass and conversion of the substrate into the product) when a nitrogen supplement was used.

Therefore, the aim of this study was to examine bioethanol production from hydrolyzed DRB by $S$. cerevisiae alcoholic fermentation employing a sequential strategy of experimental design. Two Central Composite Rotatable Designs (CCRD) were employed in order to optimize the variables of temperature, $\mathrm{pH}$, and inoculum concentration with 
respect to the response of bioethanol production. Ultrasonic treatment and protease addition were also evaluated in order to increase bioethanol production.

\section{Materials and Methods}

Raw material, enzymes, and microorganism

DRB, provided by Riograndense Rice Institute (IRGA-Pelotas/RS), was ground in a knife mill (SL31, Solab, Piracicaba, Brazil) and frozen at $-12{ }^{\circ} \mathrm{C}$ until analysis. The DRB was submitted to enzymatic hydrolysis by amylolytic enzymes used industrially in the production of rice vinegar thermostable $\alpha$-amylase (Termamyl 2X, Novozymes, Bagsværd, Denmark) and amyloglucosidase (AMG 300L, Novozymes) and protease (Alcalase $2.4 \mathrm{~L} \mathrm{FG}$, Novozymes), all provided by LNF - Latin America. After hydrolysis, alcoholic fermentation was carried out using $S$. cerevisiae (commercial lyophilized yeast, Saf-instant, Campinas, Brazil).

\section{Amylolytic enzymatic hydrolysis of $D R B$}

DRB was hydrolyzed enzymatically as previously described by Siepmann, Canan, Jesus, Pazuch, \& Colla (2018) in order to release fermentable sugars. Then $\alpha$-amylase (30 $\left.\mu \mathrm{L} \mathrm{g}^{-1} \mathrm{DRB}\right)$ was added to the DRB suspension (200 $\left.\mathrm{g} \mathrm{L}^{-1}\right)$, and $\mathrm{pH} 6.0$ and a temperature of $90{ }^{\circ} \mathrm{C}$ were maintained for $2 \mathrm{~h}$. For amyloglucosidase (40 $\left.\mu \mathrm{L} \mathrm{g}^{-1} \mathrm{DRB}\right)$ hydrolysis, the suspension was cooled, and the temperature and $\mathrm{pH}$ were adjusted to $55{ }^{\circ} \mathrm{C}$ and 4.7 , respectively and maintained for $3 \mathrm{~h}$. Subsequently, the sugar profile of hydrolyzed DRB was determined according to Stobienia et al. (2020). An ultra-high-performance liquid chromatograph (Ultimate 3000, Thermo Scientific, Germering, Germany), equipped with an automatic sample injector, quaternary pump, oven, and refraction index (RI) detector and controlled by Chromeleon 7.0 software was used. The extract was filtered $(0.45 \mu \mathrm{m}$; Millipore, Massachusetts, USA) and injected $(20 \mu \mathrm{L})$ into the chromatograph. A BioRad Aminex HPX-87H (300 mm × 7.8 mm, $9 \mu \mathrm{m}$ particle size) column and a mobile phase composed of $\mathrm{H}_{2} \mathrm{SO}_{4} 5.0 \mathrm{mM}$ at a flow rate of $0.6 \mathrm{~mL} \mathrm{m^{-1 }}$ were used. The oven temperature was set at $50{ }^{\circ} \mathrm{C}$, and detection was performed by IR at $210 \mathrm{~nm}$. The following standards were used: glucose, fructose, xylose, arabinose, mannose, maltose, and galactose, all from Sigma-Aldrich (Saint Louis, USA). The sugar profile of hydrolyzed DRB evidencing a glucose content of $58.04 \mathrm{~g} \mathrm{~L}^{-1}$, a maltose content of $3.08 \mathrm{~g} \mathrm{~L}^{-1}$, and a mixture of galactose, xylose, mannose, and fructose of $4.58 \mathrm{~g} \mathrm{~L}^{-1}$, arabinose was not detected.

Sequential strategy of experimental design for the alcoholic fermentation of DRB

Alcoholic fermentation was carried out in three steps (Figure 1). The first one was performed by CCRD in order to evaluate the effect of temperature, $\mathrm{pH}$, and inoculum concentration on bioethanol production (CCRD-A). Subsequently, an ultrasound and protease (US+P), and a protease only $(\mathrm{P})$ treatment were tested in order to increase the conversion of substrate (DRB) into bioethanol. Lastly, a second CCRD was performed considering the variables temperature and inoculum concentration on bioethanol production (CCRD-B) taking into account a previous treatment of substrate with protease $(\mathrm{P})$. CCRD-A and B were performed using three central points, without repetition; however, the response variables were determined in triplicate. CCRD-A and B followed a generic model detailed in Equation 1 and 2, respectively.

$$
\begin{gathered}
y=\beta_{0}+\beta_{1} \cdot x_{1}+\beta_{1} \cdot x_{1}{ }^{2}+\beta_{2} \cdot x_{2}+\beta_{2} \cdot x_{2}{ }^{2}+\beta_{3} \cdot x_{3}+\beta_{3} \cdot x_{3}{ }^{2}+\beta_{12} \cdot x_{1} \cdot x_{2}+\beta_{13} \cdot x_{1} \cdot x_{3}+\beta_{23} \cdot x_{2} \cdot x_{3} \\
y=\beta_{0}+\beta_{1} \cdot x_{1}+\beta_{1} \cdot x_{1}{ }^{2}+\beta_{2} \cdot x_{2}+\beta_{2} \cdot x_{2}{ }^{2}+\beta_{12} \cdot x_{1} \cdot x_{2}
\end{gathered}
$$




\section{CCRD-A ( $\left.2^{3}\right)$}

DRB submited to amylolytic hydrolysis ( $5 \mathrm{~h}$ )

Variables: $\left(\mathrm{x}_{1}\right)$ temperature $\left(25\right.$ to $\left.30^{\circ} \mathrm{C}\right)$

$\left(\mathrm{x}_{2}\right) \mathrm{pH}(4.0$ to 6.0$)$

$\left(\mathrm{x}_{3}\right)$ inoculum concentration $\left(0.5\right.$ to $\left.50 \mathrm{~g} \mathrm{~L}^{-1}\right)$

Response: bioethanol production $\left(\mathrm{g} \mathrm{L}^{-1}\right)$
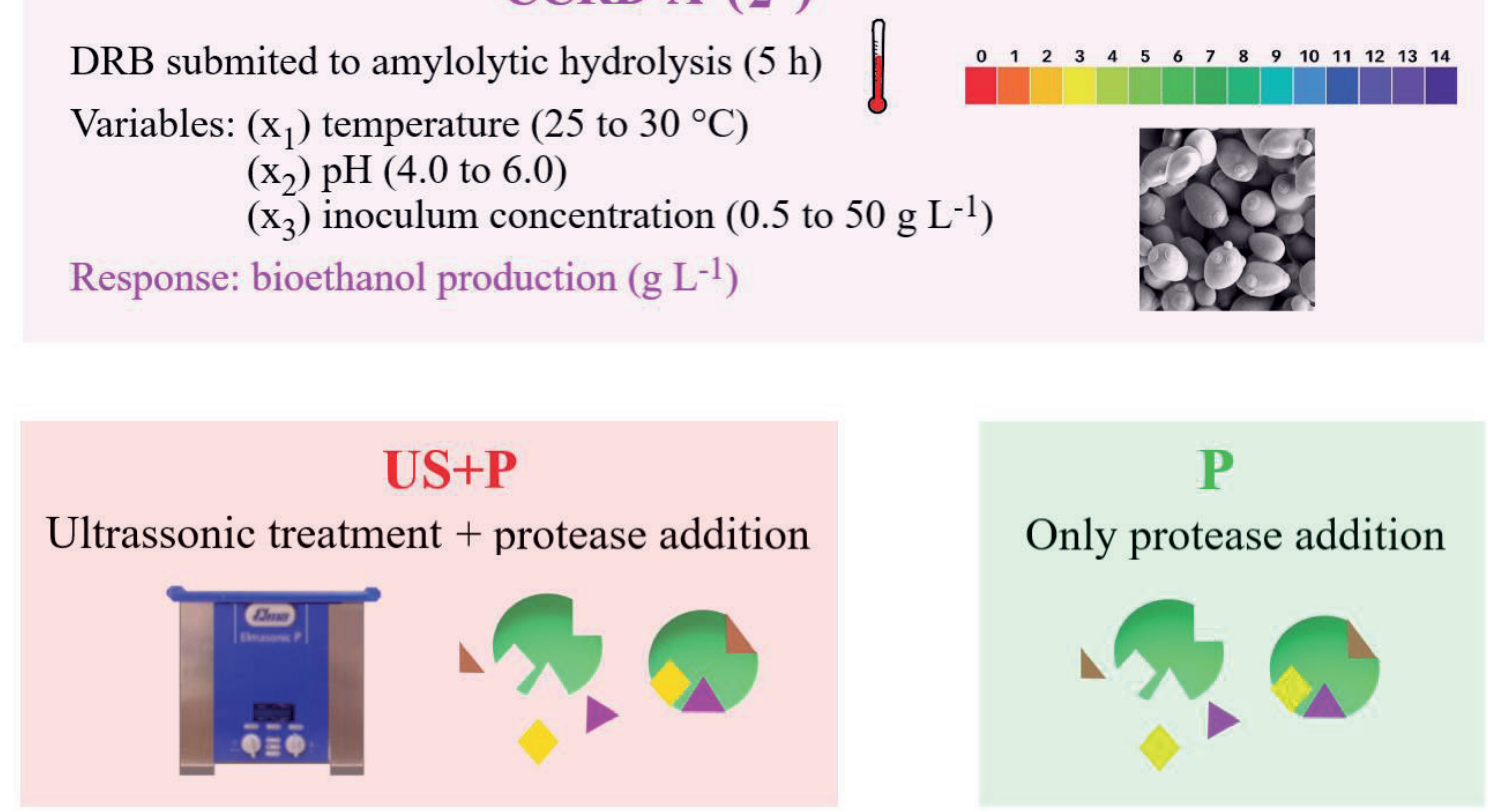

\section{CCRD-B (2)}

DRB submited to protease $(2 \mathrm{~h})$ and amylolytic $(5 \mathrm{~h})$ hydrolysis ( $\mathrm{pH} 5.0)$

Variables: $\left(\mathrm{x}_{1}\right)$ temperature $\left(28\right.$ to $\left.35^{\circ} \mathrm{C}\right)$

$\left(\mathrm{x}_{2}\right)$ : inoculum concentration $\left(10\right.$ to $\left.70 \mathrm{~g} \mathrm{~L}^{-1}\right)$

Response: bioethanol production $\left(\mathrm{g} \mathrm{L}^{-1}\right)$

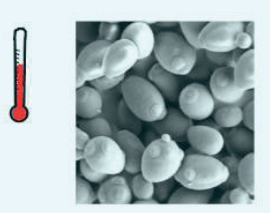

Figure 1. Flowchart sequence of tests carried out during the study of the hydrolyzed defatted rice bran alcoholic fermentation.

\section{CCRD-A}

First, a CCRD $\left(2^{3}\right.$ plus star configuration, 3 central points, total of 17 runs) referred to as CCRD-A, was applied. The effect of temperature $\left(25\right.$ to $\left.30{ }^{\circ} \mathrm{C}\right)\left(\mathrm{x}_{1}\right), \mathrm{pH}(4.0$ to 6.0$)\left(\mathrm{x}_{2}\right)$, and inoculum concentration (5.0 to $\left.50.0 \mathrm{~g} \mathrm{~L}^{-1}\right)\left(\mathrm{x}_{3}\right)$ were studied in order to evaluate the response of bioethanol concentration $\left(\mathrm{g} \mathrm{L}^{-1}\right)$ (Table 1). The variables used in the process and their levels were defined by preliminary tests (data not shown). All runs were conducted in $500 \mathrm{~mL}$ Erlenmeyer flasks. After the enzymatic hydrolysis, DRB suspension temperature and $\mathrm{pH}$ were adjusted before the inoculum addition following the experimental design (Table 1). All runs were incubated in a shaker (SL 221, Solab) under a stationary state. 
Application of ultrasonic treatment and protease addition

In order to evaluate the possibility of increasing bioethanol production by CCRD-A, ultrasonic treatment (Elmasonic P 120 H, Singen, Germany) and protease addition prior to amylolytic hydrolysis were performed in two sets of experiments. In the first (US+P), the DRB suspension was exposed to ultrasonic treatment(frequency $37 \mathrm{kHz}$, power $100 \%$, temperature $30{ }^{\circ} \mathrm{C}$ for $5 \mathrm{~min}$ ) following protease addition $\left(15 \mu \mathrm{L} \mathrm{g}^{-1} \mathrm{DRB}, \mathrm{pH} 6.5\right.$, temperature $60^{\circ} \mathrm{C}$ for $2 \mathrm{~h}$ ). In the second $(\mathrm{P})$, protease was added to the DRB suspension under the same conditions as in the first, without ultrasonic treatment. After the US+P and $\mathrm{P}$ treatment, sugar hydrolysis was performed as described previously, followed by alcoholic fermentation. The parameters used in alcoholic fermentation were defined by the results obtained in CCRD-A (temperature $30^{\circ} \mathrm{C}, \mathrm{pH} 5.0$, and inoculum concentration $50 \mathrm{~g} \mathrm{~L}^{-1}$ ), conducted in a shaker (SL 221 , Solab) in a stationary state.

Table 1

Matrix of CCRD-A with coded and real values (in parenthesis) of the variables studied and responses of reducing sugar, biomass, and concentration of bioethanol - after $48 \mathrm{~h}$ of alcoholic fermentation process

\begin{tabular}{cccccccc}
\hline Run & $\mathrm{x}_{1}{ }^{\mathrm{a}}$ & $\mathrm{x}_{2}{ }^{\mathrm{b}}$ & $\mathrm{x}_{3}{ }^{\mathrm{c}}$ & $\begin{array}{c}\text { Reducing sugar } \\
(0 \mathrm{~h})\left(\mathrm{g} \mathrm{L}^{-1}\right)^{\mathrm{d}}\end{array}$ & $\begin{array}{c}\text { Reducing sugar } \\
(48 \mathrm{~h})\left(\mathrm{g} \mathrm{L}^{-1}\right)^{\mathrm{d}}\end{array}$ & $\begin{array}{c}\text { Biomass } \\
\left(\mathrm{g} \mathrm{L}^{-1}\right)^{\mathrm{d}}\end{array}$ & $\begin{array}{c}\text { Bioethanol } \\
\left(\mathrm{g} \mathrm{L}^{-1}\right)^{\mathrm{d}}\end{array}$ \\
\hline 1 & $-1(26.0)$ & $-1(4.4)$ & $-1(14.0)$ & $67.25 \pm 1.89$ & $0.46 \pm 0.21$ & $34.74 \pm 2.09$ & $16.10 \pm 0.24$ \\
2 & $+1(29.0)$ & $-1(4.4)$ & $-1(14.0)$ & $66.23 \pm 2.71$ & $0.22 \pm 0.08$ & $34.37 \pm 4.08$ & $18.10 \pm 0.18$ \\
3 & $-1(26.0)$ & $+1(5.6)$ & $-1(14.0)$ & $64.82 \pm 2.64$ & $0.31 \pm 0.15$ & $31.55 \pm 4.33$ & $17.20 \pm 0.35$ \\
4 & $+1(29.0)$ & $+1(5.6)$ & $-1(14.0)$ & $64.23 \pm 1.09$ & $0.16 \pm 0.12$ & $37.93 \pm 0.57$ & $15.40 \pm 0.31$ \\
5 & $-1(26.0)$ & $-1(4.4)$ & $+1(41.0)$ & $66.90 \pm 0.97$ & $0.53 \pm 0.42$ & $80.16 \pm 6.87$ & $16.60 \pm 0.06$ \\
6 & $+1(29.0)$ & $-1(4.4)$ & $+1(41.0)$ & $63.76 \pm 1.24$ & $0.15 \pm 0.08$ & $59.23 \pm 4.30$ & $19.40 \pm 0.32$ \\
7 & $-1(26.0)$ & $+1(5.6)$ & $+1(41.0)$ & $66.50 \pm 1.23$ & $0.27 \pm 0.20$ & $67.91 \pm 10.27$ & $19.50 \pm 0.14$ \\
8 & $+1(29.0)$ & $+1(5.6)$ & $+1(41.0)$ & $65.09 \pm 1.55$ & $0.24 \pm 0.11$ & $60.70 \pm 3.68$ & $20.40 \pm 0.14$ \\
9 & $-1,68(25.0)$ & $0(5.0)$ & $0(28.0)$ & $66.46 \pm 1.01$ & $0.23 \pm 0.15$ & $50.31 \pm 2.87$ & $18.25 \pm 0.07$ \\
10 & $+1,68(30.0)$ & $0(5.0)$ & $0(28.0)$ & $66.31 \pm 0.59$ & $0.31 \pm 0.23$ & $67.96 \pm 0.64$ & $19.10 \pm 0.09$ \\
11 & $0(27.5)$ & $-1,68(4.0)$ & $0(28.0)$ & $66.42 \pm 0.77$ & $0.55 \pm 0.21$ & $59.67 \pm 1.05$ & $14.10 \pm 0.11$ \\
12 & $0(27.5)$ & $+1.68(6.0)$ & $0(28.0)$ & $68.42 \pm 1.43$ & $0.35 \pm 0.23$ & $75.12 \pm 5.23$ & $16.82 \pm 0.14$ \\
13 & $0(27.5)$ & $0(5.0)$ & $-1,68(5.0)$ & $67.13 \pm 0.67$ & $0.33 \pm 0.02$ & $19.59 \pm 0.96$ & $15.30 \pm 0.08$ \\
14 & $0(27.5)$ & $0(5.0)$ & $+1,68(50.0)$ & $66.19 \pm 1.09$ & $0.57 \pm 0.08$ & $113.34 \pm 9.11$ & $17.47 \pm 0.21$ \\
15 & $0(27.5)$ & $0(5.0)$ & $0(28.0)$ & $66.86 \pm 1.52$ & $0.28 \pm 0.16$ & $62.37 \pm 2.31$ & $15.95 \pm 0.11$ \\
16 & $0(27.5)$ & $0(5.0)$ & $0(28.0)$ & $67.21 \pm 0.73$ & $0.34 \pm 0.18$ & $69.16 \pm 0.94$ & $16.43 \pm 0.14$ \\
17 & $0(27.5)$ & $0(5.0)$ & $0(28.0)$ & $66.07 \pm 0.76$ & $0.29 \pm 0.03$ & $62.28 \pm 4.83$ & $16.21 \pm 0.21$ \\
\hline
\end{tabular}

${ }^{\mathrm{a}}$ Temperature $\left({ }^{\circ} \mathrm{C}\right) ;{ }^{\mathrm{b}} \mathrm{pH} ;{ }^{\mathrm{c}}$ Inoculum concentration $\left(\mathrm{g} \mathrm{L}^{-1}\right) ;{ }^{\mathrm{d}}$ Result expressed by mean \pm standard deviation $(\mathrm{n}=3)$.

\section{$C C R D-B$}

In order to improve bioethanol production, after the CCRD-A and the US+P and P treatment, a second CCRD, referred to as CCRD-B was conducted. The DRB suspension with protease was applied $\left(15 \mu \mathrm{L} \mathrm{g}^{-1} \mathrm{DRB}\right.$, temperature $60{ }^{\circ} \mathrm{C}$ and 2 h), without exposure to ultrasonic treatment. Sugar hydrolysis was performed as described previously, followed by alcoholic fermentation. 
For the CCRD-B, the significant variable ranges applied in CCRD-A were adjusted. Thus, in the CCRD-B ( $2^{2}$ plus star configuration, 3 central points, total of 11 runs) the effect of temperature (28 to $\left.35^{\circ} \mathrm{C}\right)\left(\mathrm{x}_{1}\right)$ and inoculum concentration $(10$ to $\left.70 \mathrm{~g} \mathrm{~L}^{-1}\right)\left(\mathrm{x}_{2}\right)$ were studied in order to evaluate the response of bioethanol concentration $\left(\mathrm{g} \mathrm{L}^{-1}\right)$
(Table 2). All runs were conducted in $500 \mathrm{~mL}$ Erlenmeyer flasks. Before inoculum addition, the $\mathrm{pH}$ of the DRB suspension was adjusted to 5.0 (fixed variable), and the temperature was adjusted following the experimental design (Table 2). All runs were incubated in a shaker (SL 221, Solab) in a stationary state.

\section{Table 2}

Matrix of CCRD-B with coded and real values (in parenthesis) of the variables and responses of reducing sugar, biomass, and concentration of bioethanol observed and predicted - after $36 \mathrm{~h}$ of alcoholic fermentation process

\begin{tabular}{ccccccccc}
\hline Run & $\mathrm{x}_{1}{ }^{\mathrm{a}}$ & $\mathrm{x}_{2}^{\mathrm{b}}$ & $\begin{array}{c}\text { Reducing } \\
\text { sugar }(0 \mathrm{~h}) \\
\left(\mathrm{g} \mathrm{L}^{-1}\right)^{\mathrm{c}}\end{array}$ & $\begin{array}{c}\text { Reducing } \\
\text { sugar }(36 \mathrm{~h}) \\
\left(\mathrm{g} \mathrm{L}^{-1}\right)^{\mathrm{c}}\end{array}$ & $\begin{array}{c}\text { Biomass } \\
\left(\mathrm{g} \mathrm{L}^{-1}\right)^{\mathrm{c}}\end{array}$ & $\begin{array}{c}\text { Observed } \\
\text { bioethanol } \\
\left(\mathrm{g} \mathrm{L}^{-1}\right)^{\mathrm{c}}\end{array}$ & $\begin{array}{c}\text { Predicted } \\
\text { bioethanol } \\
\left(\mathrm{g} \mathrm{L}^{-1}\right)^{\mathrm{d}}\end{array}$ & $\begin{array}{c}\text { Relative } \\
\text { deviation } \\
(\%)^{\mathrm{e}}\end{array}$ \\
\hline 1 & $-1(29.0)$ & $-1(18.5)$ & $67.25 \pm 1.89$ & $0.35 \pm 0.21$ & $20.88 \pm 1.38$ & $39.20 \pm 0.35$ & 39.19 & 0.03 \\
2 & $+1(34.0)$ & $-1(18.5)$ & $63.23 \pm 2.71$ & $0.80 \pm 0.08$ & $20.44 \pm 3.64$ & $36.50 \pm 0.28$ & 35.99 & 1.40 \\
3 & $-1(29.0)$ & $+1(61.5)$ & $64.82 \pm 2.64$ & $0.41 \pm 0.15$ & $102.80 \pm 2.40$ & $38.70 \pm 0.21$ & 38.69 & 0.03 \\
4 & $+1(34.0)$ & $+1(61.5)$ & $64.23 \pm 1.09$ & $0.45 \pm 0.12$ & $116.48 \pm 2.45$ & $40.40 \pm 0.06$ & 39.89 & 1.26 \\
5 & $-1.41(28.0)$ & $0(40.0)$ & $66.90 \pm 0.42$ & $0.36 \pm 0.41$ & $97.93 \pm 0.21$ & $37.90 \pm 0.12$ & 37.83 & 0.19 \\
6 & $+1.41(35.0)$ & $0(40.0)$ & $63.76 \pm 1.24$ & $0.41 \pm 0.08$ & $93.84 \pm 1.54$ & $35.80 \pm 0.30$ & 36.42 & -1.73 \\
7 & $0(31.5)$ & $-1.41(10.0)$ & $66.50 \pm 1.23$ & $0.61 \pm 0.02$ & $37.04 \pm 1.73$ & $38.30 \pm 0.09$ & 38.57 & -0.70 \\
8 & $0(31.5)$ & $+1.41(70.0)$ & $65.01 \pm 1.55$ & $0.34 \pm 0.01$ & $185.89 \pm 2.56$ & $40.70 \pm 0.21$ & 40.97 & -0.65 \\
9 & $0(31.5)$ & $0(40.0)$ & $66.46 \pm 0.99$ & $0.46 \pm 0.23$ & $97.53 \pm 2.72$ & $39.38 \pm 0.08$ & 39.29 & 0.23 \\
10 & $0(31.5)$ & $0(40.0)$ & $66.31 \pm 0.59$ & $0.54 \pm 0.21$ & $101.09 \pm 1.33$ & $39.07 \pm 0.04$ & 39.19 & -0.56 \\
11 & $0(31.5)$ & $0(40.0)$ & $66.43 \pm 0.76$ & $0.56 \pm 0.11$ & $102.57 \pm 0.60$ & $39.43 \pm 0.11$ & 35.99 & 0.36 \\
\hline
\end{tabular}

${ }^{\mathrm{a}}$ Temperature $\left({ }^{\circ} \mathrm{C}\right) ;{ }^{\mathrm{b}}$ Inoculum concentration $\left(\mathrm{g} \mathrm{L}^{-1}\right) ;{ }^{\mathrm{c}}$ Results expressed by mean \pm standard deviation $(\mathrm{n}=3) ;{ }^{\mathrm{d}}$ Bioethanol values predicted by the model $\left(\mathrm{g} \mathrm{L}^{-1}\right)$; ${ }^{\mathrm{e}}$ Relative deviation $=((\mathrm{Y}-\hat{\mathrm{Y}}) / \mathrm{Y}) * 100$; where $\mathrm{Y}=$ observed bioethanol and $\hat{\mathrm{Y}}=$ predicted bioethanol by the model.

\section{Validation of alcoholic DRB fermentation}

Validation of the optimized conditions for the step of alcoholic fermentation was carried out in a benchtop bioreactor (Bioreactor Tec-Bio 4,5 L, Tecnal, Piracicaba, Brazil), using $3.0 \mathrm{~L}$ of DRB suspension and fixing the temperature $\left(31.5^{\circ} \mathrm{C}\right), \mathrm{pH}$ (5.0), and inoculum concentration $\left(50 \mathrm{~g} \mathrm{~L}^{-1}\right)$.

\section{Sampling interval}

For CCRD-A, CCRD-B, US+P, and $\mathrm{P}$ experiments, samples were collected every $12 \mathrm{~h}$ to determine the bioethanol concentration and every
$6 \mathrm{~h}$ to monitor the biomass and reducing sugar (RS) concentration. In the validation step of DRB alcoholic fermentation, all analyses (biomass, RS, and bioethanol concentration) were performed at intervals of $12 \mathrm{~h}$. All analyses were conducted in triplicate.

\section{Determination of reducing sugars and biomass (dry} cell weight)

The concentration of RS was determined using the method of Somogyi (1945) and Nelson (1944), and the results were expressed in $\mathrm{g} \mathrm{L}^{-1}$. 
The concentration of cellular biomass was determined as dry cell weight in $\mathrm{g} \mathrm{L}^{-1}$. The optical density (OD) of culture medium aliquots was read in a spectrophotometer (Lambda XLS, Perkin Elmer, Beaconsfield, United Kingdom) at $600 \mathrm{~nm}$ using calibration curves of OD versus dry mass in $\mathrm{g} \mathrm{L}^{-1}$.

\section{Determination of bioethanol concentration}

Bioethanol concentration was determined in an ultra-high-performance liquid chromatograph (UPLC) (Ultimate 3000, Thermo Scientific Germering, Germany), equipped with an automatic sample injector, quaternary pump, oven, and refraction index (RI) detector, controlled by Chromeleon 7.0 software. The samples were filtered in a $0.45 \mu \mathrm{m}$ nylon membrane (Millipore, Massachusetts, USA) and injected (20 $\mu \mathrm{L})$ into an UHPLC. A Rezex ${ }^{\circledR}$ ROA-Organic Acid H+ $(8 \%)$ column (Phenomenex, Torrance, USA) and an oven temperature of $30{ }^{\circ} \mathrm{C}$ were employed. An isocratic elution with $5 \mathrm{Mm} \mathrm{H}_{2} \mathrm{SO}_{4}$ at a flow rate of $0.6 \mathrm{~mL}$ $\mathrm{min}^{-1}$ was applied (Stobienia et al., 2020).

Yield and kinetic parameters of alcoholic fermentation

The yield $(\mathrm{Y})$ of the alcoholic fermentation of CCRD-B was calculated using Eq. 3.

$$
Y(\%)=\frac{\left[\mathrm{E}_{\mathrm{f}}-\left[\mathrm{E}_{0}\right]\right.}{\left(\left[\mathrm{RS}_{0}\right]-[\mathrm{RS}]_{\mathrm{f}}\right) \times 0.511} \times 100
$$

Where: [E] and [RS] are the bioethanol and reducing sugar concentrations at a given time $(\mathrm{f}=\mathrm{final} ; 0=$ initial). The value $0.511 \mathrm{~g} \mathrm{~g}^{-1}$ corresponds to the stoichiometric conversion of RS into bioethanol for S. cerevisiae.

The conversion factors of ethanol yield from sugar $\left(\mathrm{Y}_{\mathrm{P} / \mathrm{S}}\right)$ and into biomass yield $\left(\mathrm{Y}_{\mathrm{X} / \mathrm{S}}\right)$ and of ethanol yield from biomass $\left(\mathrm{Y}_{\mathrm{P} / \mathrm{X}}\right)$ were calculated using Eq. 4, 5, and 6.

$$
\begin{aligned}
& Y_{P / S}=\frac{P_{f}-P}{S_{0}-S_{f}} \\
& Y_{X / S}=\frac{X_{f}-X}{S_{0}-S_{f}} \\
& Y_{P / X}=\frac{P_{f}-P_{0}}{X_{f}-X_{0}}
\end{aligned}
$$

Where: $\mathrm{P}_{0}$ and $\mathrm{P}_{\mathrm{f}}$ are the initial and final bioethanol concentrations $\left(\mathrm{g} \mathrm{L}^{-1}\right) ; \mathrm{X}_{0}$ and $\mathrm{X}_{\mathrm{f}}$ are the initial and final biomass $\left(\mathrm{g} \mathrm{L}^{-1}\right)$; and $\mathrm{S}_{0}$ and $\mathrm{S}_{\mathrm{f}}$ are the initial and final substrate $(\mathrm{RS})$ concentrations $\left(\mathrm{g} \mathrm{L}^{-1}\right)$.

\section{Statistical treatment of the data}

CCRD-A and CCRD-B runs were conducted randomly, and the data were analyzed by the Experimental Design procedure of Statistica 8.0 software (Statsoft Inc., Tulsa, USA). The adequacy of the second-order models was expressed by the determination coefficient $\left(\mathrm{R}^{2}\right)$ and adjusted $\mathrm{R}^{2}\left(\mathrm{R}^{2}\right.$ adj). Statistical significance was determined by ANOVA. A significance level of 5\% was considered $(p<0.05)$. Moreover, the kinetic parameters were compared by Tukey's test $(\mathrm{p}<0.05)$ using the abovementioned software.

\section{Results and Discussion}

Optimization of temperature, $p H$, and inoculum concentration for bioethanol production from $D R B$ - CCRD-A

Alcoholic fermentation was carried out for $72 \mathrm{~h}$; however, it was observed that in $48 \mathrm{~h}$, $99 \%$ of the substrate was consumed. The initial $(0 \mathrm{~h}) \mathrm{RS}$ concentration (between 63.76 and 68.42 $\left.\mathrm{g} \mathrm{L}^{-1}\right)$ reached levels from 0.15 to $0.57 \mathrm{~g} \mathrm{~L}^{-1}$ after $48 \mathrm{~h}$ of alcoholic fermentation (Table 1), allowing a bioethanol concentration between 14.10 (run 11) and $20.40 \mathrm{~g} \mathrm{~L}^{-1}$ (run 8) (Table 1). The results for biomass concentration varied between 19.59 and $113.34 \mathrm{~g}$ $\mathrm{L}^{-1}$. It became apparent that the final concentration of biomass varied according to the initial addition of inoculum. It is important to emphasize that the 
initial concentration of $S$. cerevisiae was between $9.25 \times 10^{7}$ and $1.65 \times 10^{9}$ cells $\mathrm{mL}^{-1}$ for inoculum concentrations of 5 and $50 \mathrm{~g} \mathrm{~L}^{-1}$, respectively.

Table 3 shows the effects of the variables studied in CCRD-A. The quadratic term of temperature $\left(\mathrm{x}_{1}\right)$ and the linear term of inoculum concentration $\left(\mathrm{x}_{3}\right)$ had a significant positive effect on bioethanol production by $S$. cerevisiae from DRB. The results indicate that an increase in these variable ranges resulted in a bioethanol concentration increase. In contrast, the $\mathrm{pH}$ had a non-significant effect on the response $(p>0.05)$ in the range studied.

Table 3

Effects of the variables studied on CCRD-A $2^{3}$ and CCRD-B $2^{2}$ for the responses concentration of bioethanol $\left(\mathrm{g} \mathrm{L}^{-1}\right)$ and analysis of variance (ANOVA) of the quadratic model for prediction of bioethanol $\left(\mathrm{g} \mathrm{L}^{-1}\right)$ of the CCRD-A and CCRD-B

\begin{tabular}{|c|c|c|c|c|c|c|c|c|c|c|}
\hline \multicolumn{5}{|c|}{ Effects } & \multicolumn{6}{|c|}{ Analysis of variance } \\
\hline Parameter & Effect & $\begin{array}{l}\text { Standard } \\
\text { error }\end{array}$ & $\mathrm{t}(7)$ & p-value & $\begin{array}{l}\text { Source of } \\
\text { variation }\end{array}$ & $\begin{array}{c}\text { Sum of } \\
\text { square }\end{array}$ & $\begin{array}{l}\text { Degrees of } \\
\text { freedom }\end{array}$ & $\begin{array}{l}\text { Mean } \\
\text { square }\end{array}$ & p-value & $\begin{array}{c}\mathrm{F} \\
\text { ratio }^{\mathrm{a}}\end{array}$ \\
\hline & \multicolumn{4}{|c|}{$C C R D-A$} & \multicolumn{6}{|c|}{$C C R D-A$} \\
\hline Mean & 16.13 & 0.50 & 31.99 & $<0.000^{*}$ & $\begin{array}{l}\text { Regres- } \\
\text { sion }\end{array}$ & 42.93 & 8 & 5.37 & $0.004 *$ & 7.97 \\
\hline $\mathrm{x}_{1}(\mathrm{~L})$ & 0.78 & 0.47 & 1.65 & 0.143 & Residual & 5.39 & 8 & 0.67 & & \\
\hline $\mathrm{x}_{1}(\mathrm{Q})$ & 2.18 & 0.52 & 4.18 & $0.004 *$ & Lack of fit & 5.27 & 6 & 0.88 & 0.354 & 14.64 \\
\hline $\mathrm{x}_{2}(\mathrm{~L})$ & 1.01 & 0.47 & 2.12 & 0.071 & Pure error & 0.12 & 2 & 0.06 & & \\
\hline $\mathrm{x}_{2}(\mathrm{Q})$ & -0.09 & 0.52 & -0.18 & 0.861 & Total & 48.32 & 16 & & \multirow{2}{*}{\multicolumn{2}{|c|}{$\mathrm{R}^{2}$-adj $=77 \%$}} \\
\hline $\mathrm{x}_{3}(\mathrm{~L})$ & 1.87 & 0.47 & 3.94 & $0.006^{*}$ & & \multicolumn{3}{|c|}{$\mathrm{R}^{2}=89 \%$} & & \\
\hline $\mathrm{x}_{3}(\mathrm{Q})$ & 0.56 & 0.52 & 1.07 & 0.319 & & & \multicolumn{2}{|l|}{$\mathrm{F}_{0.05 ; 8 ; 8}=3.44$} & \multicolumn{2}{|c|}{$\mathrm{F}_{0.05 ; 6 ; 2}=19.33$} \\
\hline $\mathrm{x}_{1}$ by $\mathrm{x}_{2}$ & -1.43 & 0.62 & -2.30 & 0.055 & & & & & & \\
\hline$x_{1}$ by $x_{3}$ & 0.878 & 0.62 & 1.41 & 0.200 & & & & & & \\
\hline $\mathrm{x}_{2}$ by $\mathrm{x}_{3}$ & 1.38 & 0.62 & 2.22 & 0.062 & & & & & & \\
\hline \multicolumn{5}{|c|}{$C C R D-B$} & \multicolumn{6}{|c|}{$C C R D-B$} \\
\hline Mean & 39.29 & 0.27 & 143.41 & $<0.000^{*}$ & $\begin{array}{l}\text { Regres- } \\
\text { sion }\end{array}$ & 19.60 & 5 & 3.92 & $0.004 *$ & 17.41 \\
\hline $\mathrm{x}_{1}(\mathrm{~L})$ & -0.99 & 0.34 & -2.96 & $0.032 *$ & Residual & 1.13 & 5 & 0.23 & & \\
\hline $\mathrm{x}_{1}(\mathrm{Q})$ & -2.19 & 0.40 & -5.46 & $0.003 *$ & Lack of fit & 1.05 & 3 & 0.35 & 0.310 & 9.20 \\
\hline $\mathrm{x}_{2}(\mathrm{~L})$ & 1.70 & 0.34 & 5.06 & $0.004 *$ & Pure error & 0.08 & 2 & 0.04 & & \\
\hline $\mathrm{x}_{2}(\mathrm{Q})$ & 0.48 & 0.40 & 1.19 & 0.287 & Total & 20.73 & 10 & & & \\
\hline $\mathrm{x}_{1}$ by $\mathrm{x}_{2}$ & 2.20 & 0.47 & 4.64 & $0.006^{*}$ & & \multicolumn{3}{|c|}{$\mathrm{R}^{2}=95 \%$} & \multicolumn{2}{|c|}{$\mathrm{R}^{2}-\mathrm{adj}=90 \%$} \\
\hline & & & & & & \multicolumn{3}{|c|}{$\mathrm{F}_{0.05 ; 5 ; 5}=5.05$} & \multicolumn{2}{|c|}{$\mathrm{F}_{0.05 ; 3 ; 2}=19.16$} \\
\hline
\end{tabular}

CCRD-A: $\mathrm{x}_{1}=$ Temperature $\left({ }^{\circ} \mathrm{C}\right) ; \mathrm{x}_{2}=\mathrm{pH} ; \mathrm{x}_{3}=$ Inoculum concentration $\left(\mathrm{g} \mathrm{L}^{-1}\right) ;{ }^{*} \mathrm{p}<0.05$.

CCRD-B: $\mathrm{x}_{1}=$ Temperature $\left({ }^{\circ} \mathrm{C}\right) ; \mathrm{x}_{2}=$ Inoculum concentration $\left(\mathrm{g} \mathrm{L}^{-1}\right) ;{ }^{*} \mathrm{p}<0.05$.

${ }^{\mathrm{a}} \mathrm{F}$ ratio $=$ model significance $(\mathrm{F}$ ratio $=$ Mean Square regression/Mean Square residual or Mean Square Lack of fit/Mean Square Pure error); ${ }^{*} \mathrm{p}<0.05$. 
A valid quadratic model (with $\mathrm{R}^{2}=0.89$ and $\mathrm{R}^{2}$ $\operatorname{adj}=0.77$ ) was obtained for bioethanol production (Table 3). Non-significant effects were incorporated into the residual of the model, except in cases in which the effect influenced the $\mathrm{R}^{2}$-adj negatively. The $\mathrm{F}_{\text {calculated }}$ was significant for the regression $(\mathrm{p}=$ 0.004) and was not significant for the Lack of Fit ( $p$ $=0.354)$, indicating that the results are explained by the regression and not by the variations in the process. In addition, the percentage of the variation explained by the model was adequate $\left(\mathrm{R}^{2}=89 \%\right)$, considering the inherent variability of bioprocesses (Rodrigues \& Iemma, 2014). Thus, the model was considered well-adjusted to the experimental data, and the response surface is presented in Figure 2a. It may be observed from the response surface and contour plot that the highest concentrations of bioethanol were obtained by employing the maximum temperature and inoculum concentrations studied.
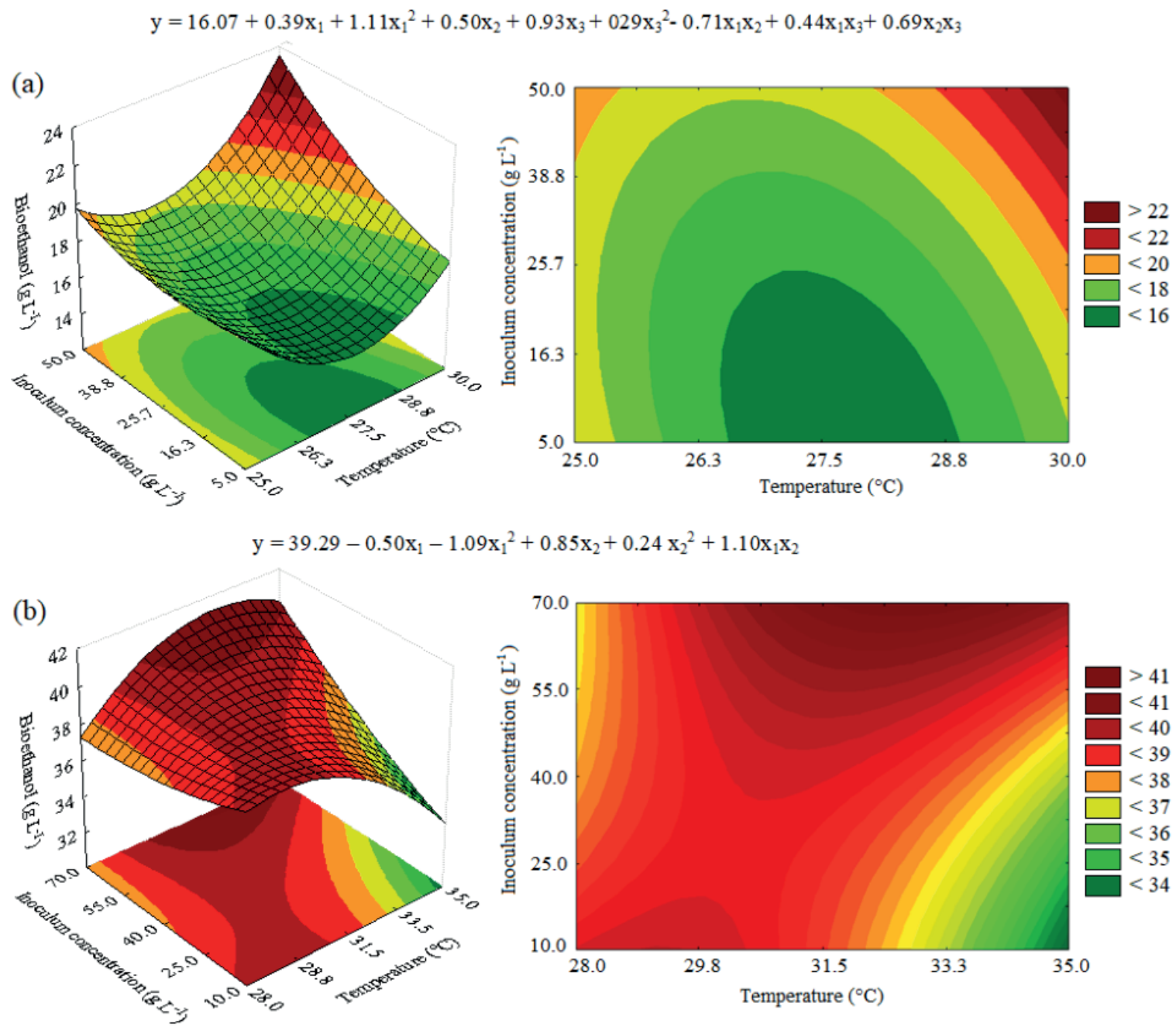

Figure 2. (a) Model, surface response and contour plot for bioethanol concentration ( $\left.\mathrm{g} \mathrm{L}^{-1}\right)$ in function of temperature $\left({ }^{\circ} \mathrm{C}\right)$ and inoculum concentration $\left(\mathrm{g} \mathrm{L}^{-1}\right)$ of CCRD-A - after $48 \mathrm{~h}$ of alcoholic fermentation; (b) Model, surface response and contour plot for bioethanol concentration $\left(\mathrm{g} \mathrm{L}^{-1}\right)$ in function of temperature $\left({ }^{\circ} \mathrm{C}\right)$ and inoculum concentration $\left(\mathrm{g} \mathrm{L}^{-1}\right)$ of CCRD-B - after $36 \mathrm{~h}$ of alcoholic fermentation. 
Theoretically, $1.0 \mathrm{~g}$ of glucose should produce $0.511 \mathrm{~g}$ of bioethanol (Caldeirão, Tanaka, Ida, \& Spinosa, 2016). However, in the CCRD-A $1.0 \mathrm{~g}$ of glucose resulted in a maximum of 0.29 $\mathrm{g}$ of bioethanol. It should be possible to obtain approximately $35 \mathrm{~g} \mathrm{~L}^{-1}$ bioethanol using the DRB. However, during alcoholic fermentation, the presence of protein and lipids may reduce the performance of yeasts (Watanabe et al., 2009a) since they are unable to consume complex compounds. DRB presented significant concentrations of protein (18\%) (Watanabe et al., 2019), which was probably responsible for the low yield of bioethanol observed. In order to reduce the concentration of proteins in the DRB suspension, ultrasound treatment and protease addition were evaluated.
Application of ultrasonic treatment and protease addition to increase bioethanol production from $D R B$

The results obtained for DRB with US+P and $\mathrm{P}$ addition are shown in Figure 3. The two experiments (US $+\mathrm{P}$ and $\mathrm{P}$ ) presented biomass and RS kinetic similarities. For $\mathrm{P}$ a significant increase in the rate of conversion of substrate into bioethanol in the first $6 \mathrm{~h}$ was observed. After 24 $\mathrm{h}$, the biomass demonstrates a higher growth rate, and the RS concentration approaches zero. These results indicate that the alcoholic fermentation process of DRB can be completed in $24 \mathrm{~h}$. Significant differences between the US $+\mathrm{P}$ and $\mathrm{P}$ were not observed for these responses $(p>0.05$ by Tukey's test). In both experiments, the substrate was consumed faster than observed in CCRD-A (24 $\mathrm{h}$ versus $48 \mathrm{~h}$ ).

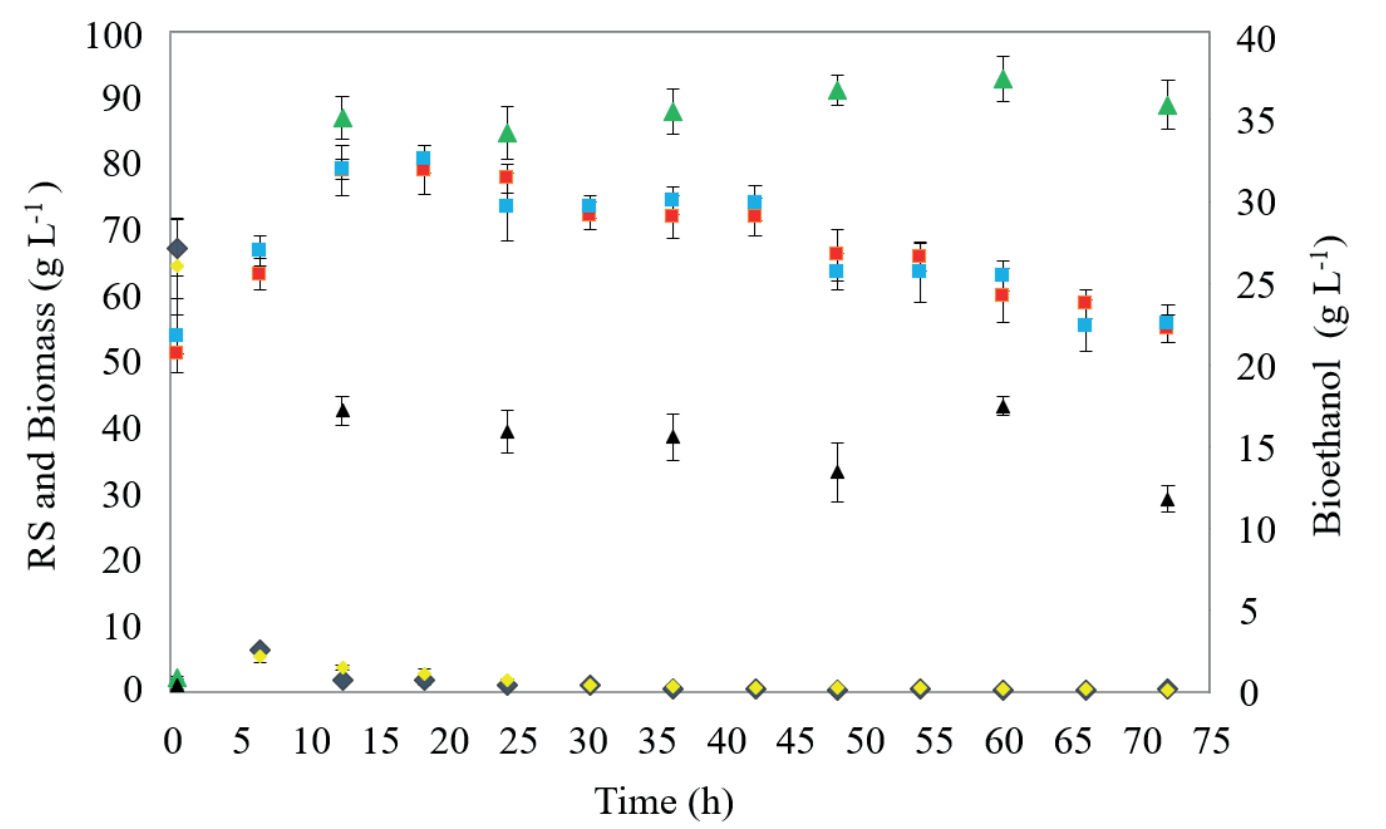

- RS (without ultrasonic treatment and with protease)

- RS (with ultrasonic treatment and protease)

- Biomass (without ultrasonic treatment and with protease) - Biomass (with ultrasonic treatment and protease)

$\Delta$ Bioethanol (without ultrasonic treatment and with protease) $\Delta$ Bioethanol (with ultrasonic treatment and protease)

Figure 3. Kinetic profile of reducing sugar (RS), biomass and bioethanol production for experiments with ultrasonic treatment and protease addition on hydrolyzed defatted rice bran. 
However, experiment $\mathrm{P}$ allowed high bioethanol production (36 $\left.\mathrm{g} \mathrm{L}^{-1}\right)$ from DRB related to US+P (11 $\mathrm{g} \mathrm{L} \mathrm{L}^{-1}$ ). Thus, comparing the maximum bioethanol concentration produced in $\mathrm{P}\left(36 \mathrm{~g} \mathrm{~L}^{-1}\right)$ with CCRD-A (20.4 $\mathrm{g} \mathrm{L}^{-1}$; Table 1), an increase of $76 \%$ was observed. Protease addition positively affects bioethanol production, reaching a yield of $100 \%$, similar to the $101 \%$ obtained by Singh \& Singh (2007). Considering the CCRD-A variables with positive effects on increasing bioethanol concentration, the $\mathrm{P}$ step was included in order to improve bioethanol production. The variables temperature and inoculum concentration were adjusted, and a second CCRD was performed, named CCRD-B.

Protease addition and optimization of temperature and inoculum concentration on bioethanol production from DRB - CCRD-B

After $36 \mathrm{~h}$ of alcoholic fermentation, $99 \%$ of the substrate ( $0 \mathrm{~h}$ RS from 63.23 to $67.25 \mathrm{~g} \mathrm{~L}^{-1}$ ) was consumed, resulting in final $\mathrm{RS}$ values between 0.34 and $0.80 \mathrm{~g} \mathrm{~L}^{-1}$. At the same time, the highest concentrations of bioethanol were observed for all runs, indicating a reduction of $12 \mathrm{~h}$ in the fermentation time (48 $\mathrm{h}$ for CCRD-A and $36 \mathrm{~h}$ for CCRD-B). Therefore, the time of $36 \mathrm{~h}$ was chosen for statistical analysis of the bioethanol yield responses. The biomass values varied between 20.44 and 185.89 $\mathrm{g} \mathrm{L}^{-1}$, and the bioethanol concentration in CCRD-B runs varied from 35.80 to $40.70 \mathrm{~g} \mathrm{~L}^{-1}$, and runs 4 and 8 had the highest bioethanol concentration (40.40 and $40.70 \mathrm{~g} \mathrm{~L}^{-1}$, respectively) (Table 2). Comparing the higher bioethanol production of CCRD-B with those reported in the CCRD-A $\left(20.4 \mathrm{~g} \mathrm{~L}^{-1}\right)$, an increase of $99 \%$ in bioethanol concentration was observed.

Table 3 shows the effects of the variables studied in CCRD-B. The linear and quadratic terms of temperature $\left(\mathrm{x}_{1}\right)$ had a significant negative effect on bioethanol production, probably due to the diminishing metabolic activity of the yeast. In contrast, the linear term of inoculum concentration $\left(\mathrm{x}_{2}\right)$, and the interaction $\mathrm{x}_{1}$ by $\mathrm{x}_{2}$ had a significant positive effect on increasing the bioethanol concentration.

A valid quadratic model (with $\mathrm{R}^{2}=0.95$ and $\mathrm{R}^{2}$ $\operatorname{adj}=0.90$ ) was obtained for bioethanol production for CCRD-B (Table 3) considering all parameters. The $\mathrm{F}_{\text {calculated }}$ for the regression was significant $(\mathrm{p}=$ 0.004), while the Lack of Fit was not significant ( $p$ $=0.310)$, indicating that the results are explained by the regression. The model was considered welladjusted to the experimental data, and the response surface is presented in Figure 2b. It may be observed from the response surface and contour plot that the highest concentrations of bioethanol were obtained in the region of temperature between 31.5 and 33.5 ${ }^{\circ} \mathrm{C}$, and $70 \mathrm{~g} \mathrm{~L}^{-1}$ of inoculum, which coincides with the condition of run $8\left(31.5{ }^{\circ} \mathrm{C}\right.$ and $70 \mathrm{~g} \mathrm{~L}^{-1}$ of inoculum).

\section{CCRD-B yield and conversion factors}

The yield and the conversion factors $\mathrm{Y}_{\mathrm{P} / \mathrm{S}}, \mathrm{Y}_{\mathrm{X} / \mathrm{S}}$, and $Y_{P / X}$ for CCRD-B runs are shown in Table 4 for CCRD-B. The yield varied between 93.26 and $113.57 \%$; run 8 had the highest yield, and only two runs (5 and 6) had yields lower than $100 \%$. Similarly, Das et al. (2013) reported a yield of 109\% for alcoholic fermentation of hydrolyzed rice straw by an inoculum of $S$. cerevisiae and Z. mobilis. A yield higher than $100 \%$ was probably associated with endogenous fermentation by $S$. cerevisiae. According to Peppler (1970), yeasts used in food contain from $22 \%$ to $34 \%$ carbohydrates, and $S$. cerevisiae accumulates two storage carbohydrates, glycogen and trehalose (François \& Parrou, 2001), reaching a range between $21.3 \%$ and $23.3 \%$ for the sum of mannose, trehalose, glucose, and glycogen (Plata, Koch, Wechselberger, Herwig, \& Lendl, 2013).

The conversion factors $\mathrm{Y}_{\mathrm{P} / \mathrm{S}}, \mathrm{Y}_{\mathrm{X} / \mathrm{S}}$, and $\mathrm{Y}_{\mathrm{X} / \mathrm{P}}$ varied between 0.48 and $0.58 \mathrm{~g} \mathrm{~g}^{-1}, 0.06$ and $1.60 \mathrm{~g} \mathrm{~g}^{-1}$, and 0.32 and $10.02 \mathrm{~g} \mathrm{~g}^{-1}$, respectively (Table 4). For the $\mathrm{Y}_{\mathrm{P} / \mathrm{S}}$ factor, runs 1 and 4 demonstrated the highest 
results $\left(0.48\right.$ and $\left.0.58 \mathrm{~g} \mathrm{~g}^{-1}\right)$; these $\mathrm{Y}_{\mathrm{P} / \mathrm{S}}$ values are greater than those cited in the literature (between 0.31 and $0.50 \mathrm{~g} \mathrm{~g}^{-1}$ ) for the production of bioethanol from sub-products, including sugarcane bagasse, soy protein concentrate, orange peel, and corn meal (Caldeirão et al., 2016; Gutiérrez-Rivera et al., 2015; Mojović, Nikolić, Rakin, \& Vukasinović, 2006; Oberoi, Vadlani, Madl, Saida, \& Abeykoon, 2010).
The higher $\mathrm{Y}_{\mathrm{P} / \mathrm{S}}$ in the present article should be a consequence of hydrolysis of proteins by proteases. The hydrolysis step released amino acids in the medium and reduce the yeast synthesis requirement of amino acids, resulting in a higher yield of biomass per mole of glucose consumed (Kłosowski, Mikulski, Czupryński, \& Kotarska, 2010).

\section{Table 4}

Yield and conversion factors of the alcoholic fermentation of hydrolyzed defatted rice bran considering CCRD-B

\begin{tabular}{ccccc}
\hline Runs & Yield $(\%)$ & $\mathrm{Y}_{\mathrm{P} / \mathrm{S}}\left(\mathrm{g} \mathrm{g}^{-1}\right)^{\mathrm{a}}$ & $\mathrm{Y}_{\mathrm{X} / \mathrm{S}}\left(\mathrm{g} \mathrm{g}^{-1}\right)^{\mathrm{b}}$ & $\mathrm{Y}_{\mathrm{P} \mathrm{X}}\left(\mathrm{g} \mathrm{g}^{-1}\right)^{\mathrm{c}}$ \\
\hline 1 & 110.35 & 0.58 & 0.06 & 10.02 \\
2 & 103.03 & 0.53 & 0.11 & 4.50 \\
3 & 103.47 & 0.53 & 0.59 & 0.83 \\
4 & 112.02 & 0.57 & 0.78 & 0.67 \\
5 & 95.36 & 0.49 & 0.84 & 0.53 \\
6 & 93.26 & 0.48 & 0.60 & 0.78 \\
7 & 106.52 & 0.54 & 0.35 & 1.54 \\
8 & 113.57 & 0.51 & 1.60 & 0.32 \\
9 & 106.53 & 0.54 & 0.66 & 0.84 \\
10 & 105.71 & 0.54 & 0.63 & 0.86 \\
11 & 108.82 & 0.56 & 0.70 & 0.80 \\
\hline
\end{tabular}

${ }^{a}$ Yield $=(\text { experimental bioethanol concentration/maximum theoretical (stoichiometric) bioethanol concentration })^{*} 100 ;{ }^{b}$ Yield factor of ethanol yield from sugar $\left(\mathrm{Y}_{\mathrm{P} / \mathrm{S}}\right)$; ${ }^{\mathrm{c}}$ Yield factor of substrate into biomass yield $\left(\mathrm{Y}_{\mathrm{X} / \mathrm{S}}\right)$; ${ }^{\mathrm{d}}$ Yield factor of ethanol yield from biomass $\left(\mathrm{Y}_{\mathrm{P} / \mathrm{X}}\right)$.

CCRD-B run 8 had the greatest bioethanol response $\left(40.70 \mathrm{~g} \mathrm{~L}^{-1}\right)$ and presented the greatest transformation of substrate into biomass $\left(\mathrm{Y}_{\mathrm{X} / \mathrm{S}}\right)$, thereby increasing the yeast population, resulting in an increase in transformation of substrate to bioethanol. Regarding $\mathrm{Y}_{\mathrm{P} / \mathrm{X} \text {, }}$ run 1 presented the highest conversion of biomass to product justifying the concentration of bioethanol near $40 \mathrm{~g} \mathrm{~L}^{-1}$ despite having the lower inoculum concentration $\left(18 \mathrm{~g} \mathrm{~L}^{-1}\right)$ and temperature $\left(29^{\circ} \mathrm{C}\right)$.
Optimized bioethanol production by alcoholic fermentation

According to the response surface analysis (Figure 2b), the ideal point (critical values) for the variables temperature and inoculum concentration, which allowed the maximum bioethanol concentration to be calculated by the quadratic model (multiple regression), were $30.2{ }^{\circ} \mathrm{C}$ and $27.5 \mathrm{~g} \mathrm{~L}^{-1}$ inoculum. At this point, the predicted bioethanol response would be $39.2 \mathrm{~g} \mathrm{~L}^{-1}$ (for $36 \mathrm{~h}$ of fermentation). By the analysis of the results expressed in Tables 2 and 
4, the run 8 conditions (CCRD-B) were selected to be tested on a major scale (benchtop bioreactor) considering that under these conditions, the highest bioethanol concentration (40.70 $\left.\mathrm{g} \mathrm{L}^{-1}\right), \mathrm{Y}_{\mathrm{X} / \mathrm{s}}$, and intermediate $\mathrm{Y}_{\mathrm{P} / \mathrm{S}}$ were observed. However, in run 8 the high inoculum concentration $\left(70 \mathrm{~g} \mathrm{~L}^{-1}\right)$ resulted in a significant increase in medium viscosity, which implies deficient homogenization, a disadvantage for industrial applications. In this way, the validation step was conducted with a $50 \mathrm{~g} \mathrm{~L}^{-1}$ inoculum concentration.

A similar bioethanol concentration (40.1 and $41.48 \mathrm{~g} \mathrm{~L}^{-1}$ ) was reported for alcoholic fermentation of a hydrolyzed rice straw and corn stove (Das et al., 2013; Zhu et al., 2015). Das et al. (2013) performed alkaline and acid hydrolysis of rice straw with subsequent washing and enzymatic hydrolysis by $\beta$-glucosidase for $48 \mathrm{~h}$. In addition, an associative culture of $S$. cerevisiae and Z. mobilis (rate 1.53) was used as the inoculum. Thus, it is apparent that the hydrolysis process carried out by these authors was slower ( $48 \mathrm{~h}$ versus $7 \mathrm{~h}$ in the present article, considering the action time of the enzymes) and more expensive to achieve the same bioethanol concentration.

In contrast, other articles reported the production of bioethanol from by-products in lower concentrations than those obtained in this article. The highest concentration of bioethanol produced from rice bran fermented by Zymomonas mobilis was $13.4 \pm 2.4 \mathrm{~g} \mathrm{~L}^{-1}$ (72.47\% for theoretical bioethanol yield) (Todhanakasem, Sangsutthiseree, Areerat, Young, \& Thanonkeo, 2014). In the fermentation of rice hull hydrolysates, Dagnino, Chamorro, Romano, Felissia, and Area (2013) obtained a conversion of $84 \%$ and $4.4 \mathrm{~g} \mathrm{~L}^{-1}$ of bioethanol. Liu et al. (2015) realized alkali-pretreated in the sugarcane bagasse supplemented with wheat bran, followed by enzymatic hydrolysis and alcoholic fermentation to obtain $5.8 \mathrm{~g} \mathrm{~L}^{-1}$ bioethanol (40.84\% of theoretical yield).

The bioethanol production and the conversion yield of DRB by alcoholic fermentation using $S$. cerevisiae in the current work was higher than reported in the literature. Furthermore, only industrial enzymes (currently used in rice hydrolysis) without chemical treatments were applied using a short processing time, indicating the innovation and relevance of the present article in bioethanol production from DRB.

\section{Validation of alcoholic fermentation}

The greatest conversion of substrate into product occurred during the first $36 \mathrm{~h}$ of fermentation, reaching $98 \%$ consumption of the original substrate (71.28 $\mathrm{g} \mathrm{L}^{-1}$ ) (Table 5). In the same time, the maximum concentration of biomass was obtained (106.38 $\mathrm{g} \mathrm{L}^{-1}$ ), indicating the end of the $\log$ phase. After $36 \mathrm{~h}$, the concentration of biomass decreased; however, the bioethanol concentration increased up to the end of the process ( $72 \mathrm{~h}$ ) reaching $40.0 \mathrm{~g} \mathrm{~L}^{-1}$ and $109.9 \%$ yield. During yeast autolysis, carbon and nitrogen are released into the medium and can be used as substrates by live yeasts. 
Table 5

Results for model validation of alcoholic fermentation of hydrolyzed defatted rice bran in a benchtop bioreactor

\begin{tabular}{cccc}
\hline Time $(\mathrm{h})$ & Bioethanol $\left(\mathrm{g} \mathrm{L}^{-1}\right)^{\mathrm{a}}$ & Reducing sugar $\left(\mathrm{g} \mathrm{L}^{-1}\right)^{\mathrm{a}}$ & Dry Mass $\left(\mathrm{g} \mathrm{L}^{-1}\right)^{\mathrm{a}}$ \\
\hline 0 & $9.1 \pm 0.02$ & $71.28 \pm 4.47$ & $51.52 \pm 1.09$ \\
12 & $27.6 \pm 0.04$ & $3.45 \pm 0.33$ & $101.14 \pm 6.11$ \\
24 & $27.4 \pm 0.08$ & $1.31 \pm 2.02$ & $102.78 \pm 1.26$ \\
36 & $28.1 \pm 0.02$ & $1.17 \pm 1.86$ & $106.38 \pm 0.03$ \\
48 & $36.1 \pm 0.01$ & $0.94 \pm 0.58$ & $91.98 \pm 0.09$ \\
60 & $36.7 \pm 0.02$ & $0.50 \pm 0.46$ & $77.26 \pm 0.18$ \\
72 & $40.0 \pm 0.01$ & $0.43 \pm 0.71$ & $74.57 \pm 0.78$ \\
\hline
\end{tabular}

${ }^{a}$ Result expressed by mean \pm standard error $(n=3)$.

The greater concentration of bioethanol obtained during alcoholic fermentation in CCRD-B (40.7 g $\mathrm{L}^{-1}$ of run 8 , at $36 \mathrm{~h}$ fermentation, conducted in 500 $\mathrm{mL}$ Erlenmeyer flasks) was similar ( $\mathrm{p}>0.05$ by Tukey's test) to the maximum values obtained in the validation experiment carried out in the benchtop bioreactor (40.0 $\mathrm{g} \mathrm{L}^{-1}$, at $72 \mathrm{~h}$ of fermentation). However, the differences in total ethanol productivity observed must be considered, which probably occurred due to the scale increase and consequent homogenization trouble, since the fermentation was carried out without agitation and aeration. Moreover, the decrease in the inoculum concentration, from 70 to $50 \mathrm{~g} \mathrm{~L}^{-1}$ should also have induced a decrease in bioethanol. As previously mentioned, the inoculum concentration of $70 \mathrm{~g} \mathrm{~L}^{-1}$ caused a marked increase in culture medium viscosity. A more detailed study of scaling up could help increase the bioethanol productivity of the system.

\section{Conclusion}

The hydrolysis of DBR proteins by treatment with protease before amylolytic hydrolysis and alcoholic fermentation by $S$. cerevisiae allowed an increase in final bioethanol production. The temperature and inoculum concentration generate effects ( $p>$ 0.05 ) on bioethanol production, while the $\mathrm{pH}$, in the range studied, had no influence on the conversion of substrate into product. The temperature of 31.5
${ }^{\circ} \mathrm{C}$ and an inoculum concentration of $70 \mathrm{~g} \mathrm{~L}^{-1}$ was the optimized condition for $40.70 \mathrm{~g} \mathrm{~L}^{-1}$ bioethanol production by alcoholic fermentation. Validation in a benchtop bioreactor produced $40.0 \mathrm{~g} \mathrm{~L}^{-1}$ of bioethanol from DRB previously hydrolyzed with protease and amylolytic enzymes. The results obtained suggest that the use of a strategy of sequential design and protease addition contributes to the improvement of bioethanol production from DRB. Additionally, the bioethanol concentration and yield obtained in this study demonstrate that the DRB alcoholic fermentation process for bioethanol production is industrially viable. Furthermore, the DRB proved to be a by-product with great potential for bioethanol production, derived from alternative sources not commonly used in human food.

\section{Acknowledgement}

This study was financed in part by the Coordenação de Aperfeiçoamento de Pessoal de Nível Superior - Brasil (CAPES) -Finance Code 001, CNPq, and Fundação Araucária.

\section{References}

Amagliani, L., O’Regan, J., Kelly, A. L., \& O’Mahony, J. A. (2017). Composition and protein profile analysis of rice protein ingredients. Journal of Food Composition and Analysis, 59, 19-26. doi: 10. 1016/j. jfca.2016.12.026 
Caldeirão, L., Tanaka, C., Ida, E., \& Spinosa, W. (2016). Modeling and kinetic study of bio-ethanol production from soy protein concentrate by-product. Food Science and Technology, 36(2), 369-374. doi: 10.1590/1678-457X.0021

Companhia Nacional de Abastecimento (2020). Acompanhamento da safra brasileira de grãos. Recuperado de https://www.conab.gov.br/info-agro/ safras/graos

Dagnino, E. P., Chamorro, E. R., Romano, S. D., Felissia, F. E., \& Area, M. C. (2013). Optimization of the acid pretreatment of rice hulls to obtain fermentable sugars for bioethanol production. Industrial Crops and Products, 42, 363-368. doi: 10.1016/j. indcrop.2012.06.019

Das, A., Paul, T., Jana, A., Halder, S. K., Ghosh, K., Maity, C.,... Mondal, K. C. (2013). Bioconversion of rice straw to sugar using multizyme complex of fungal origin and subsequent production of bioethanol by mixed fermentation of Saccharomyces cerevisiae MTCC 173 and Zymomonas mobilis MTCC 2428. Industrial Crops and Products, 46, 217-225. doi: 10.1016/j.indcrop.2013.02.003

François, J., \& Parrou, J. L. (2001). Reserve carbohydrates metabolism in the yeast Saccharomyces cerevisiae. FEMS Microbiology Reviews, 25(1), 125-145. doi: 10.1016/S0168-6445(00)00059-0

Gutiérrez-Rivera, B., Ortiz-Muñiz, B., GómezRodríguez, J., Cárdenas-Cágal, A., Domínguez González, J. M., \& Aguilar-Uscanga, M. G. (2015). Bioethanol production from hydrolyzed sugarcane bagasse supplemented with molasses "B" in a mixed yeast culture. Renewable Energy, 74, 399-405. doi: 10. 1016/j.renene.2014.08.030

Hayes, D. J. (2009). An examination of biorefining processes, catalysts and challenges. Catalysis Today, 145(1-2), 138-151.doi: 10.1016/j.cattod.2008.04.017

Johnston, D. B., \& McAloon, A. J. (2014). Protease increases fermentation rate and ethanol yield in drygrind ethanol production. Bioresource Technology, 154, 18-25. doi: 10.1016/j.biortech.2013.11.043

Kłosowski, G., Mikulski, D., Czupryński, B., \& Kotarska, K. (2010). Characterisation of fermentation of high-gravity maize mashes with the application of pullulanase, proteolytic enzymes and enzymes degrading non-starch polysaccharides. Journal of Bioscience and Bioengineering, 109(5), 466-471. doi: 10.1016/j.jbiosc.2009.10.024
Lei, H., Zheng, L., Wang, C., Zhao, H., \& Zhao, M. (2013). Effects of worts treated with proteases on the assimilation of free amino acids and fermentation performance of lager yeast. International Journal of Food Microbiology, 161(2), 76-83. doi: 10.1016/j. ijfoodmicro.2012.11.024

Liu, Y., Zhang, Y., Xu, J., Sun, Y., Yuan, Z., \& Xie, J. (2015). Consolidated bioprocess for bioethanol production with alkali-pretreated sugarcane bagasse. Applied Energy, 157, 517-522. doi: 10.1016/j. apenergy.2015.05.004

Mendes-Ferreira, A., Mendes-Faia, A., \& Leão, C. (2004). Growth and fermentation patterns of Saccharomyces cerevisiae under different ammonium concentrations and its implications in winemaking industry. Journal of Applied Microbiology, 97(3), 540-545. doi: 10.1111/j.1365-2672. 2004.02331.x

Mojović, L., Nikolić, S., Rakin, M., \& Vukasinović, M. (2006). Production of bioethanol from corn meal hydrolyzates. Fuel, 85(12-13), 1750-1755. doi: 10.1016/j.fuel.2006.01.018

Nelson, N. (1944). A photometric adtation of the Somogyi methid for the determination of glucose. The Journal of Biological Chemistry, 3(2), 375-380.

Oberoi, H. S., Vadlani, P. V., Madl, R. L., Saida, L., \& Abeykoon, J. P. (2010). Ethanol production from orange peels: twostage hydrolysis and fermentation studies using optimized parameters through experimental design. Journal of Agricultural and Food Chemistry, 58(6), 3422-3429. doi: 10.1021/ jf903163t

Parrado, J., Miramontes, E., Jover, M., Gutierrez, J. F., Collantes de Terán, L., \& Bautista, J. (2006). Preparation of a rice bran enzymatic extract with potential use as functional food. Food Chemistry, 98(4), 742-748. doi: 10.1016/j. foodchem.2005.07.016

Peppler, H. (1970). Food yeats. In A. H. Rose, \& J. S. Harrison (Eds.), The yeasts (pp. 421-463). London: Academin Press.

Plata, M. R., Koch, C., Wechselberger, P., Herwig, C., \& Lendl, B. (2013). Determination of carbohydrates present in Saccharomyces cerevisiae using midinfrared spectroscopy and partial least squares regression. Analytical and Bioanalytical Chemistry, 405(25), 8241-8250. doi: 10.1007/s00216-0137239-9 
Rodrigues, M. I., \& Iemma, A. F. (2014). Experimental design and process optimization. Boca Raton: CRC Press.

Siepmann, F. B., Canan, C., Jesus, M. M. M. de, Pazuch, C. M., \& Colla, E. (2018). Release optimization of fermentable sugars from defatted rice bran for bioethanol production. Acta Scientiarum. Technology, 40(1), 35000. doi: 10.4025/ actascitechnol.v40i1.35000

Singh, R., \& Singh, S. (2007). Design and development of batch type acetifier for wine-vinegar production. Indian Journal of Microbiology, 47(2), 153-159. doi: 10.1007/s12088-007-0029-3

Somogyi, M. (1945). A new reagent for the determination of sugars. The Journal of Biological Chemistry, 160, 61-68.

Stobienia, M., Kalschne, D. L., Peron-Schlosser, B., Colla, L. M., Baraldo, I. J., \& Colla, E. (2020). Evaluation of ultrasound waves on S. cerevisiae stimulation in the bioethanol production from rice bran. BioEnergy Research, 13, 314324. doi: 10.1007/ s12155-019-10088-5

Todhanakasem, T., Sangsutthiseree, A., Areerat, K., Young, G. M., \& Thanonkeo, P. (2014). Biofilm production by Zymomonas mobilis enhances ethanol production and tolerance to toxic inhibitors from rice bran hydrolysate. New Biotechnology, 31(5), 451459. doi: $10.1016 /$ j.nbt.2014.06.002
Watanabe, M., Honda, H., Kashiwamura, T., Sasano, K., \& Watanabe, K. (2009a). Sedimentation and flocculating properties of solid particles in enzymatic treated rice washing drainage and its mechanism. Japan Journal of Food Engineering, 8, 165-172. doi: $10.11301 /$ jsfe. 10.55

Watanabe, M., Takahashi, M., Sasano, K., Kashiwamura, T., Ozaki, Y., Tsuiki, T.,... Kanemoto, S. (2009b). Bioethanol production from rice washing drainage and rice bran. Journal of Bioscience and Bioengineering, 108(6), 524-526. doi: 10.1016/j. jbiosc.2009.06.014

Watanabe, M., Yamada, C., Maeda, I., Techapun, C., Kuntiya, A., Leksawasdi, N.,... Endo, S. (2019). Evaluating of quality of rice bran protein concentrate prepared by a combination of isoelectronic precipitation and electrolyzed water treatment. $L W T$, 99, 262-267. doi: 10.1016/j.lwt.2018.09.059

Yao, L., Lee, S. L., Wang, T., Moura, J. M. L. N. de, \& Johnson, L. A. (2012). Effects of fermentation substrate conditions on corn-soy co-fermentation for fuel ethanol production. Bioresource Technology, 120, 140-148. doi: 10.1016/j.biortech.2012.04.071

Zhu, J., Rong, Y., Yang, J., Zhou, X., Xu, Y., Zhang, L.,... Yu, S. (2015). Integrated production of xylonic acid and bioethanol from acid-catalyzed steamexploded corn stover. Applied Biochemistry and Biotechnology, 176(5), 1370-1381. doi: 10.1007/ s12010-015-1651-x 